\title{
Radiopharmaceuticals for Nuclear Cardiology: Radiation Dosimetry, Uncertainties, and Risk
}

\author{
Michael G. Stabin \\ Department of Radiology and Radiological Sciences, Vanderbilt University, Nashville, Tennessee
}

The technical basis for the dose estimates for several radiopharmaceuticals used in nuclear cardiology is reviewed, and cases in which uncertainty has been encountered in the dosimetry of an agent are discussed. Also discussed is the issue of uncertainties in radiation dose estimates and how to compare the relative risks of studies. Methods: Radiation dose estimates (organ absorbed doses and effective doses) from different literature sources were directly compared. Typical values for administered activity per study were used to compare doses that are to be expected in clinical applications. Results: The effective doses for all agents varied from 2 to $15 \mathrm{mSv}$ per study, with the lowest values being seen for ${ }^{13} \mathrm{~N}-\mathrm{NH}_{3}$ and ${ }^{15} \mathrm{O}-\mathrm{H}_{2} \mathrm{O}$ studies and the highest values being seen for ${ }^{201} \mathrm{Tl}$-chloride studies. The effective doses for 99mTc- and ${ }^{201} \mathrm{TI}-$ labeled agents differed by about a factor of 2 , a factor that is comparable to the uncertainty in individual values. This uncertainty results from the application of standard anthropomorphic and biokinetic models, presumably representative of the exposed population, to individual patients. Conclusion: Considerations such as diagnostic accuracy, ease of use, image quality, and patient comfort and convenience should generally dictate the choice of a radiopharmaceutical, with radiation dose being only a secondary or even tertiary consideration. Counseling of nuclear medicine patients who may be concerned about exposure should include a reasonable estimate of the median dose for the type of examination and administered activity of the radiopharmaceutical; in addition, it should be explained that the theoretic risks of the procedure are orders of magnitude lower than the actual benefits of the examination. Providing numeric estimates of risks from studies to individual patients is inappropriate, given the uncertainties in the dose estimates and the limited predictive power of current dose-risk models in the low-dose (i.e., diagnostic) range.

Key Words: radiation dosimetry; nuclear cardiology; uncertainty; risk

J Nucl Med 2008; 49:1555-1563

DOI: 10.2967/jnumed.108.052241

Received Feb. 27, 2008; revision accepted Jul. 8, 2008

For correspondence or reprints contact: Michael G. Stabin, Department of Radiology and Radiological Sciences, Vanderbilt University, 116121 st Ave. South, Nashville, TN 37232-2675.

E-mail: michael.g.stabin@vanderbilt.edu

COPYRIGHT @ 2008 by the Society of Nuclear Medicine, Inc.
$\mathbf{S}$ recent years for cardiac imaging in nuclear medicine. The dosimetry (i.e., published doses) of these agents may be quite different, and dosimetry issues for several of these agents have generated some confusion and concern. Here the technical basis for the dose estimates for various agents used in nuclear cardiology is described and differences in the dosimetry of the agents are discussed. Product package inserts, limited dose compendia, and other sources sometimes have presented conflicting and confusing information about the dosimetry of these agents. Practitioners sometimes have expressed concern about how differences in radiation dosimetry may affect the choice of a radiopharmaceutical. The dosimetry (organ absorbed doses and effective doses) of radiopharmaceuticals currently used in nuclear cardiology is reviewed, and uncertainties in the dose estimates are discussed. Relative radiation risks for these radiopharmaceuticals also are discussed. The principal motivation for this effort was to address questions from nuclear cardiologists about whether a particular radiopharmaceutical is preferred over another on the basis of their respective radiation risks. In addition, I describe an analysis demonstrating that the differences in most radiation dose estimates for the agents in question are small compared with the absolute uncertainties of these estimates. The use of risk models in evaluating the radiation risks of diagnostic studies also is briefly discussed.

\section{MATERIALS AND METHODS}

Radiation dose estimates (organ doses and effective doses) from different literature sources were directly compared. The most widely cited sources are publications of the Task Group on Radiopharmaceutical Dosimetry of the International Commission on Radiological Protection (ICRP), which has published dose estimates for various compounds, as has the Radiation Internal Dose Information Center (RIDIC); those recommendations are reviewed and compared here. The MIRD group of the Society of Nuclear Medicine has published dose estimate reports for only one of the agents used in nuclear cardiology and therefore has not provided much helpful guidance in this area, but the one contribution from the MIRD group is considered. Tabulated values of dose per unit of administered activity $(\mathrm{mSv} / \mathrm{MBq})$ are presented, and typical values of administered activity per study were 
used to compute and compare doses (mSv) that are to be expected clinically.

\section{RESULTS}

\section{${ }^{201}$ TI-Chloride}

${ }^{201} \mathrm{Tl}$-chloride $\left({ }^{201} \mathrm{Tl}\right.$ half-life $\left.=72.9 \mathrm{~h}\right)$ (thallous chloride), administered as an intravenous bolus injection, has been used for several decades to image the myocardium. The radiation dosimetry of ${ }^{201}$ Tl-chloride was first established in 1977 by Atkins et al. (1), who showed that the initial clearance of ${ }^{201} \mathrm{Tl}$-chloride from blood is characterized by a rapidly decreasing biexponential function, with $91.5 \%$ of blood radioactivity disappearing with a half-time of approximately $5 \mathrm{~min}$ and the other $8.5 \%$ having a halftime of about $40 \mathrm{~h}$. The uptake of ${ }^{201} \mathrm{Tl}$-chloride by organs such as the liver, kidneys, heart, and intestines varied widely. Another study of the biokinetics of thallous chloride was performed later, by Krahwinkel et al. in 1988 (2), also with human subjects. Their results were studied and slightly modified by Castronovo (3) and were generally accepted as being similar to those of Atkins et al. (1), although obtained with more modern imaging technology. Both Atkins et al. (1) and Krahwinkel et al. (2) quantified the maximum uptake in the testes and obtained fairly similar results $(0.15 \%-0.3 \%$ of the administered activity), but studies by 2 other groups, Gupta et al. (4) and Hosain and Hosain (5), suggested values for testicular uptake at $24 \mathrm{~h}$ of $0.8 \%-1 \%$ of the administered activity. The ICRP Task Group on Radiopharmaceutical Dosimetry published dose estimates for ${ }^{201} \mathrm{Tl}$-chloride in adults and children of various ages ( 6 ) by using the data of Krahwinkel et al. (2) to characterize the doses to most organs but adopting the more conservative upper estimates of testicular activity. The high doses to the testes caused some concern over the use of ${ }^{201} \mathrm{Tl}$-chloride, particularly in younger subjects, because the doses to the testes could be higher than the doses to any other organ. Thomas et al. performed quantitative testicular scintigraphy with ${ }^{201} \mathrm{Tl}$-chloride injected after peak exercise in 28 patients (56 studies) (7) and found a mean uptake of about $0.3 \%$, in agreement with the earlier findings of Atkins et al. (1) and Krahwinkel et al. (2).

The dosimetry of ${ }^{201}$ Tl-chloride is complicated by the fact that preparations of ${ }^{201} \mathrm{Tl}$ are usually accompanied by the presence of radioactive contaminants, such as ${ }^{200} \mathrm{Tl}$, ${ }^{202} \mathrm{Tl}$, and ${ }^{203} \mathrm{~Pb}$. These contaminants do not contribute large amounts to the total doses to any organ, but their contributions must be included to provide a complete assessment of the dosimetry of the compound. The ICRP Task Group believes that the data of Thomas et al. (7) are sound and intends to revise the ICRP dose estimates in a future publication. The dose estimates for ${ }^{201} \mathrm{Tl}$ in the dosimetry compendium published by RIDIC ( 8 ) were based on the data of Krahwinkel et al. (2) and Thomas et al. (7) for doses to the testes (obtained before publication) and on the assumption of radiocontaminant levels similar to those in the study of Thomas et al.; therefore, they agreed well with the dose estimates of Thomas et al. Table 1 shows the dosimetry proposed by the 3 groups.

Table 2 shows the contributions of the radiocontaminants to the total dose, calculated from the data of Thomas et al. (7). The dosimetry values proposed by the groups are in generally good agreement, although significant differences exist between the ICRP estimates and the other 2 estimates for a few organs, including the testes (as would be expected from the 3-fold difference in modeled uptake), marrow, and thyroid. Marrow, with a tissue weighting factor of 0.12 , and the testes, with a weighting factor of 0.25 , have a considerable influence on the calculation of the effective dose and lead to the ICRP values being more than $40 \%$ higher than those suggested by Thomas et al. (7). The values of the RIDIC group and of Thomas et al. (7) are preferred and, as noted earlier, future publications by the ICRP will reflect lower dose estimates for the testes and therefore lower effective doses.

\section{9mTc-Methoxyisobutylisonitrile (99mTc-MIBI)}

${ }^{99 \mathrm{~m}}$ Tc-MIBI $\left({ }^{99 \mathrm{~m}} \mathrm{Tc}\right.$ half-life $=6.01 \mathrm{~h}$ ) (MIBI is also known as sestamibi or hexamibi) is a cationic compound prepared from a lyophilization kit (trade name: Cardiolite; Bristol-Myers Squibb Medical Imaging) and is used in studies of cardiac ventricular function and myocardial perfusion. It accumulates in viable myocardium in proportion to regional blood flow. Clearance from blood is rapid; uptake is high in the muscle, liver, and kidneys; and uptake

TABLE 1

Radiation Dosimetry for ${ }^{201} \mathrm{Tl}-$ Chloride in Adults

\begin{tabular}{llll}
\hline & \multicolumn{2}{c}{ Dose (mSv/MBq) estimated by: } \\
\cline { 2 - 4 } & & & Thomas \\
Organ & ICRP $(6)$ & RIDIC $(8)$ & et al. $(7)$ \\
\hline Adrenal glands & $5.1 \mathrm{E}-02$ & $6.3 \mathrm{E}-02$ & $6.3 \mathrm{E}-02$ \\
\hline Brain & & $5.9 \mathrm{E}-02$ & $5.7 \mathrm{E}-02$ \\
\hline Breasts & $2.8 \mathrm{E}-02$ & $3.6 \mathrm{E}-02$ & $3.4 \mathrm{E}-02$ \\
\hline Gallbladder wall & & $8.3 \mathrm{E}-02$ & $8.3 \mathrm{E}-02$ \\
\hline Lower large intestine wall & $3.6 \mathrm{E}-01$ & $3.4 \mathrm{E}-01$ & $3.0 \mathrm{E}-01$ \\
\hline Small intestine & $1.6 \mathrm{E}-01$ & $4.5 \mathrm{E}-01$ & $3.8 \mathrm{E}-01$ \\
\hline Stomach wall & $1.2 \mathrm{E}-01$ & $1.9 \mathrm{E}-01$ & $1.7 \mathrm{E}-01$ \\
\hline Upper large intestine wall & $1.9 \mathrm{E}-01$ & $3.3 \mathrm{E}-01$ & $3.0 \mathrm{E}-01$ \\
\hline Heart wall & $2.3 \mathrm{E}-01$ & $2.8 \mathrm{E}-01$ & $2.5 \mathrm{E}-01$ \\
\hline Kidneys & $5.4 \mathrm{E}-01$ & $4.6 \mathrm{E}-01$ & $4.1 \mathrm{E}-01$ \\
\hline Liver & $1.8 \mathrm{E}-01$ & $9.9 \mathrm{E}-02$ & $9.4 \mathrm{E}-02$ \\
\hline Lungs & $1.2 \mathrm{E}-01$ & $4.7 \mathrm{E}-02$ & $4.7 \mathrm{E}-02$ \\
\hline Muscle & $5.6 \mathrm{E}-02$ & $4.6 \mathrm{E}-02$ & $4.6 \mathrm{E}-02$ \\
\hline Ovaries & $1.2 \mathrm{E}-01$ & $1.0 \mathrm{E}-01$ & $1.0 \mathrm{E}-01$ \\
\hline Pancreas & $5.4 \mathrm{E}-02$ & $7.4 \mathrm{E}-02$ & $7.5 \mathrm{E}-02$ \\
\hline Red marrow & $1.8 \mathrm{E}-01$ & $5.5 \mathrm{E}-02$ & $4.4 \mathrm{E}-02$ \\
\hline Bone surfaces & $3.4 \mathrm{E}-01$ & $8.8 \mathrm{E}-02$ & $9.4 \mathrm{E}-02$ \\
\hline Skin & & $3.3 \mathrm{E}-02$ & $3.2 \mathrm{E}-02$ \\
\hline Spleen & $1.4 \mathrm{E}-01$ & $1.8 \mathrm{E}-01$ & $1.7 \mathrm{E}-01$ \\
\hline Testes & $5.6 \mathrm{E}-01$ & $2.0 \mathrm{E}-01$ & $2.1 \mathrm{E}-01$ \\
\hline Thymus & & $4.6 \mathrm{E}-02$ & $4.6 \mathrm{E}-02$ \\
\hline Thyroid & $2.5 \mathrm{E}-01$ & $6.2 \mathrm{E}-01$ & $5.4 \mathrm{E}-01$ \\
\hline Urinary bladder wall & $3.6 \mathrm{E}-02$ & $5.2 \mathrm{E}-02$ & $6.2 \mathrm{E}-02$ \\
\hline Uterus & $5.0 \mathrm{E}-02$ & $8.5 \mathrm{E}-02$ & $8.6 \mathrm{E}-02$ \\
\hline Effective dose & $2.2 \mathrm{E}-01$ & $1.6 \mathrm{E}-01$ & $1.6 \mathrm{E}-01$ \\
\hline & & & \\
\hline & & & \\
\hline
\end{tabular}


TABLE 2

Estimated Absorbed Doses at Time of Calibration from ${ }^{201} \mathrm{Tl}-$ Chloride and Contaminants After Intravenous Administration and Contribution of Each Radionuclide to Absorbed Doses

\begin{tabular}{|c|c|c|c|c|c|c|c|c|c|}
\hline \multirow[b]{2}{*}{ Organ } & \multicolumn{5}{|c|}{ Dose (mSv/MBq) of: } & \multicolumn{4}{|c|}{ Percentage contribution of: } \\
\hline & $201 \mathrm{Tl}$ & ${ }^{200} \mathrm{TI}$ & $202 \mathrm{TI}$ & ${ }^{203} \mathrm{~Pb}$ & Total & $201 \mathrm{TI}$ & $200 \mathrm{Tl}$ & $202 \mathrm{Tl}$ & ${ }^{203} \mathrm{~Pb}$ \\
\hline Adrenal glands & 5.67E-02 & $5.90 \mathrm{E}-04$ & $5.78 \mathrm{E}-03$ & $2.25 E-04$ & $6.33 E-02$ & 89.58 & 0.93 & 9.14 & 0.36 \\
\hline Brain & $5.16 \mathrm{E}-02$ & $2.92 E-04$ & 4.79E-03 & $9.06 E-05$ & $5.68 E-02$ & 90.88 & 0.51 & 8.45 & 0.16 \\
\hline Breasts & $3.10 E-02$ & $2.55 E-04$ & $2.60 E-03$ & $6.36 \mathrm{E}-05$ & $3.39 E-02$ & 91.38 & 0.75 & 7.68 & 0.19 \\
\hline Gallbladder wall & 7.44E-02 & 7.97E-04 & 7.57E-03 & $2.73 E-04$ & 8.31E-02 & 89.60 & 0.96 & 9.11 & 0.33 \\
\hline Lower large intestine wall & $2.82 E-01$ & $1.32 E-03$ & $1.22 E-02$ & 8.63E-05 & $2.96 E-01$ & 95.39 & 0.45 & 4.14 & 0.03 \\
\hline Small intestine & $3.63 E-01$ & $1.55 E-03$ & $1.44 \mathrm{E}-02$ & $9.93 E-05$ & $3.79 E-01$ & 95.77 & 0.41 & 3.80 & 0.03 \\
\hline Stomach wall & $1.61 E-01$ & $9.96 E-04$ & 9.37E-03 & $9.71 E-05$ & $1.71 E-01$ & 93.89 & 0.58 & 5.47 & 0.06 \\
\hline Upper large intestine wall & $2.80 E-01$ & $1.72 \mathrm{E}-03$ & $1.52 E-02$ & $1.10 E-04$ & 2.97E-01 & 94.27 & 0.58 & 5.11 & 0.04 \\
\hline Heart wall & $2.36 E-01$ & 1.03E-03 & $9.44 \mathrm{E}-03$ & 1.16E-04 & 2.47E-01 & 95.71 & 0.42 & 3.82 & 0.05 \\
\hline Kidneys & $3.92 E-01$ & $1.72 E-03$ & 1.63E-02 & 4.53E-04 & 4.10E-01 & 95.49 & 0.42 & 3.98 & 0.11 \\
\hline Liver & $8.62 E-02$ & $6.78 \mathrm{E}-04$ & $6.20 E-03$ & $8.17 E-04$ & $9.39 E-02$ & 91.80 & 0.72 & 6.61 & 0.87 \\
\hline Lungs & 4.31E-02 & $3.60 E-04$ & $3.78 \mathrm{E}-03$ & $1.25 E-04$ & 4.73E-02 & 90.98 & 0.76 & 8.00 & 0.27 \\
\hline Muscle & $4.15 E-02$ & $3.83 E-04$ & $3.89 E-03$ & $1.00 E-04$ & $4.59 E-02$ & 90.46 & 0.84 & 8.49 & 0.22 \\
\hline Ovaries & $9.14 \mathrm{E}-02$ & $1.00 E-03$ & $9.18 \mathrm{E}-03$ & $9.27 E-05$ & $1.02 E-01$ & 89.90 & 0.99 & 9.02 & 0.09 \\
\hline Pancreas & $6.74 \mathrm{E}-02$ & $7.06 E-04$ & $6.95 E-03$ & $1.79 E-04$ & $7.52 E-02$ & 89.59 & 0.94 & 9.23 & 0.24 \\
\hline Red marrow & $3.90 E-02$ & $4.54 \mathrm{E}-04$ & $4.55 E-03$ & $3.53 E-04$ & 4.44E-02 & 87.93 & 1.02 & 10.26 & 0.80 \\
\hline Bone surfaces & $8.59 E-02$ & $4.46 E-04$ & $5.58 E-03$ & $1.83 E-03$ & $9.37 E-02$ & 91.62 & 0.48 & 5.95 & 1.96 \\
\hline Skin & $2.89 E-02$ & 2.27E-04 & 2.37E-03 & $6.62 E-05$ & $3.16 \mathrm{E}-02$ & 91.55 & 0.72 & 7.52 & 0.21 \\
\hline Spleen & $1.55 E-01$ & $9.15 E-04$ & $9.76 E-03$ & $8.59 E-05$ & $1.66 \mathrm{E}-01$ & 93.51 & 0.55 & 5.88 & 0.05 \\
\hline Testes & $2.00 E-01$ & $7.00 E-04$ & $8.52 E-03$ & $5.95 E-05$ & $2.09 E-01$ & 95.56 & 0.34 & 4.08 & 0.03 \\
\hline Thymus & 4.17E-02 & $3.71 E-04$ & $3.83 E-03$ & $8.00 E-05$ & 4.60E-02 & 90.69 & 0.81 & 8.33 & 0.17 \\
\hline Thyroid & $5.25 \mathrm{E}-01$ & $1.44 \mathrm{E}-03$ & $1.55 E-02$ & $7.68 \mathrm{E}-05$ & $5.42 \mathrm{E}-01$ & 96.85 & 0.27 & 2.87 & 0.01 \\
\hline Urinary bladder wall & $5.66 \mathrm{E}-02$ & $5.24 \mathrm{E}-04$ & $5.34 \mathrm{E}-03$ & $6.91 E-05$ & $6.25 E-02$ & 90.50 & 0.84 & 8.55 & 0.11 \\
\hline Uterus & 7.77E-02 & 8.20E-04 & $7.76 \mathrm{E}-03$ & $8.23 E-05$ & 8.63E-02 & 89.97 & 0.95 & 8.98 & 0.10 \\
\hline
\end{tabular}

Assumed percentages of ${ }^{201} \mathrm{TI},{ }^{200} \mathrm{TI},{ }^{202} \mathrm{TI}$, and ${ }^{203} \mathrm{~Pb}$ were $98.3,0.3,1.2$, and 0.2 , respectively. Contributions of radiocontaminants to total dose were calculated from data of Thomas et al. (7); however, Thomas et al. did not report effective doses.

is lower in the thyroid and salivary glands. Excretion occurs primarily through the gastrointestinal tract. The ICRP Task Group on Radiopharmaceutical Dosimetry relied on the published data of Wackers et al. (9) and Leide et al. (10) for dose estimates; the RIDIC group published dose estimates based on internally available data from clinical trials conducted in the United States. Both groups considered differences in the observed biokinetics and doses in resting and exercising subjects. The dose estimates are shown in Table 3. Although the dose estimates were generally similar, the patients used for the RIDIC data seemed to have higher rates of urinary and gastrointestinal excretion than those in the 2 studies used by the ICRP. Therefore, the doses to many systemic organs in the RIDIC model were lower, whereas the doses to the intestines and urinary tract were higher. The latter differences resulted in RIDIC values for effective doses that were about $50 \%$ higher than the ICRP values. Because of the larger (and published) patient database used by the ICRP, the ICRP dose estimates are preferred.

\section{9mTc-Tetrofosmin}

${ }^{99 \mathrm{~m}} \mathrm{Tc}$-tetrofosmin is a lipophilic technetium phosphine dioxo cation made from a kit formulation (trade name: Myoview; GE Healthcare) and is used to study myocardial perfusion. The compound is taken up in viable myocardial tissue in proportion to regional blood flow, like ${ }^{201} \mathrm{Tl}-$ chloride. It is cleared rapidly from blood and shows marked uptake in the liver, muscle, heart wall, kidneys, and salivary glands. The ICRP Task Group on Radiopharmaceutical Dosimetry characterized dosimetry on the basis of reports by Smith et al. (11) and Higley et al. (12). No other groups have characterized the dosimetry of this agent; the ICRP values are shown in Table 4.

\section{${ }^{18}$ F-FDG}

Positron emission tomography (PET) imaging with ${ }^{18} \mathrm{~F}-$ FDG is applied for the evaluation of ventricular function in coronary artery disease. The compound accumulates in the brain and heart muscle and is excreted in urine. Early dosimetry of this agent, as established by the RIDIC group, depended on a combination of organ distribution data gathered in dogs by Gallagher et al. (13) and data for the brain and urinary bladder gathered in human subjects by Jones et al. (14) The MIRD group published a dose estimate report for ${ }^{18} \mathrm{~F}-\mathrm{FDG}$ (15) in which biokinetic data from several human studies were combined as input data for dose estimates. The ICRP, however, found discrepancies between the findings of the MIRD group and other published datasets and developed an independent assessment of dosimetry. The dose estimates did not differ markedly (Table 5), with the exception of the brain, urinary bladder wall, and pancreas. For the urinary bladder, the 
TABLE 3

Radiation Dosimetry for ${ }^{99 m}$ Tc-MIBI in Adults

\begin{tabular}{|c|c|c|c|c|}
\hline \multirow[b]{3}{*}{ Organ } & \multicolumn{4}{|c|}{ Dose (mSv/MBq) estimated by: } \\
\hline & \multicolumn{2}{|c|}{ ICRP (6) } & \multicolumn{2}{|c|}{ RIDIC (8) } \\
\hline & Resting & Exercise & Resting & Exercise \\
\hline Adrenal glands & $7.5 \mathrm{E}-03$ & $6.6 \mathrm{E}-03$ & $4.3 \mathrm{E}-03$ & $3.9 \mathrm{E}-03$ \\
\hline Brain & $5.2 \mathrm{E}-03$ & $4.4 \mathrm{E}-03$ & $1.8 \mathrm{E}-03$ & $1.9 \mathrm{E}-03$ \\
\hline Breasts & $3.8 \mathrm{E}-03$ & $3.4 \mathrm{E}-03$ & $1.7 \mathrm{E}-03$ & $1.6 \mathrm{E}-03$ \\
\hline Gallbladder wall & $3.9 \mathrm{E}-02$ & $3.3 E-02$ & $1.8 \mathrm{E}-02$ & $2.5 \mathrm{E}-02$ \\
\hline $\begin{array}{l}\text { Lower large } \\
\text { intestine wall }\end{array}$ & $1.9 \mathrm{E}-02$ & $1.6 \mathrm{E}-02$ & 3.7E-02 & $2.9 \mathrm{E}-02$ \\
\hline Small intestine & $1.5 \mathrm{E}-02$ & $1.2 \mathrm{E}-02$ & $2.7 E-02$ & $2.2 E-02$ \\
\hline Stomach wall & $6.5 E-03$ & $5.9 \mathrm{E}-03$ & $5.2 E-03$ & $4.7 \mathrm{E}-03$ \\
\hline $\begin{array}{l}\text { Upper large } \\
\text { intestine wall }\end{array}$ & $2.7 \mathrm{E}-02$ & $2.2 \mathrm{E}-02$ & $5.0 \mathrm{E}-02$ & $4.0 \mathrm{E}-02$ \\
\hline Heart wall & $6.3 E-03$ & $7.2 \mathrm{E}-03$ & $4.4 \mathrm{E}-03$ & $4.8 \mathrm{E}-03$ \\
\hline Kidneys & $3.6 \mathrm{E}-02$ & $2.6 \mathrm{E}-02$ & $1.8 \mathrm{E}-02$ & $1.5 \mathrm{E}-02$ \\
\hline Liver & $1.1 \mathrm{E}-02$ & $9.2 \mathrm{E}-03$ & $5.1 \mathrm{E}-03$ & $3.7 E-03$ \\
\hline Lungs & $4.6 \mathrm{E}-03$ & $4.4 \mathrm{E}-03$ & $2.4 \mathrm{E}-03$ & $2.2 \mathrm{E}-03$ \\
\hline Muscle & $2.9 \mathrm{E}-03$ & $3.2 \mathrm{E}-03$ & $3.7 \mathrm{E}-03$ & $3.3 \mathrm{E}-03$ \\
\hline Ovaries & $9.1 \mathrm{E}-03$ & $8.1 \mathrm{E}-03$ & $1.4 \mathrm{E}-02$ & $1.2 \mathrm{E}-02$ \\
\hline Pancreas & $7.7 \mathrm{E}-03$ & $6.9 \mathrm{E}-03$ & $5.0 \mathrm{E}-03$ & $4.6 \mathrm{E}-03$ \\
\hline Red marrow & $5.5 \mathrm{E}-03$ & $5.0 \mathrm{E}-03$ & $4.5 E-03$ & $4.0 \mathrm{E}-03$ \\
\hline Bone surfaces & $8.2 E-03$ & $7.8 \mathrm{E}-03$ & $5.8 \mathrm{E}-03$ & $5.4 \mathrm{E}-03$ \\
\hline Skin & $3.1 \mathrm{E}-03$ & $2.9 \mathrm{E}-03$ & $1.9 E-03$ & $1.8 \mathrm{E}-03$ \\
\hline Spleen & $6.5 E-03$ & $5.8 \mathrm{E}-03$ & $5.2 E-03$ & $4.0 E-03$ \\
\hline Testes & $3.8 \mathrm{E}-03$ & $3.7 \mathrm{E}-03$ & $3.5 E-03$ & $3.1 \mathrm{E}-03$ \\
\hline Thymus & $4.1 E-03$ & $4.0 E-03$ & $2.3 E-03$ & $2.3 E-03$ \\
\hline Thyroid & $5.3 E-03$ & $4.4 \mathrm{E}-03$ & $2.2 \mathrm{E}-03$ & $2.2 E-03$ \\
\hline $\begin{array}{l}\text { Urinary bladder } \\
\text { wall }\end{array}$ & $1.1 \mathrm{E}-02$ & $9.8 \mathrm{E}-03$ & 3.7E-02 & $2.7 \mathrm{E}-02$ \\
\hline Uterus & $7.8 \mathrm{E}-03$ & $7.2 \mathrm{E}-03$ & $1.2 \mathrm{E}-02$ & $1.0 \mathrm{E}-02$ \\
\hline Effective dose & $9.0 E-03$ & $7.9 \mathrm{E}-03$ & $1.3 E-02$ & $9.5 \mathrm{E}-03$ \\
\hline
\end{tabular}

MIRD estimates were based on an irregular bladder voiding interval; therefore, the MIRD dose estimates cannot be directly compared with the other 2 sets of dose estimates. Human datasets are always preferred over animal datasets; therefore, the ICRP and MIRD estimates are more reliable than the RIDIC data. The ICRP estimates include all of the datasets used by RIDIC and MIRD as well as other recent data sources and therefore are preferred.

\section{${ }^{82} \mathrm{Rb}$-Chloride}

${ }^{82} \mathrm{Rb}$-chloride $\left({ }^{82} \mathrm{Rb}\right.$ half-life $\left.=1.27 \mathrm{~min}\right)$ is a short-lived tracer used for myocardial perfusion imaging. Ryan et al. performed a study with human subjects in 1985 (16). The ICRP Task Group on Radiopharmaceutical Dosimetry, although acknowledging the work of Ryan et al., opted for a flow-based model for the tracer, assigning timeactivity integrals for organs on the basis of their relative blood flow. Therefore, the dose estimates are somewhat different (Table 6). The ICRP model is preferred because it was published more recently and because it included a critical analysis of the model used by Ryan et al.

\section{${ }^{13} \mathrm{~N}-$ Ammonia $\left({ }^{13} \mathrm{~N}-\mathrm{NH}_{3}\right)$}

${ }^{13} \mathrm{~N}$-ammonia $\left({ }^{13} \mathrm{~N}-\mathrm{NH}_{3}\right)$ has been used for several decades for the evaluation of myocardial blood flow. Both the ICRP Task Group on Radiopharmaceutical Dosimetry and the RIDIC group used the data of Lockwood et al. (17) to establish the kinetics of ${ }^{13} \mathrm{~N}-\mathrm{NH}_{3}\left({ }^{13} \mathrm{~N}\right.$ half-life $=9.97$ $\mathrm{min}$ ), but the ICRP used a slightly different interpretation of the model and obtained somewhat different dose estimates. As shown in Table 7, most organ doses were quite similar, with the exception of the kidneys, and the effective doses were the same.

\section{9mTc-Labeled Red Blood Cells (RBCs)}

RBCs labeled with ${ }^{99 \mathrm{~m}} \mathrm{Tc}$ circulate in the bloodstream and are useful in the evaluation of cardiac function. They are cleared from the body with biologic half-times of 40-80 $\mathrm{h}$, and some urinary activity is detectable. The RIDIC group published dose estimates for in vitro and in vivo labeled RBCs (8) on the basis of a MIRD dose estimate report from 1990 (18). The ICRP published a single model for labeled RBCs, with a brief discussion of the uncertainties related to the use of different labeling methods. These various dose estimates are in good agreement (Table 8).

\section{${ }^{15} \mathrm{O}-\mathrm{H}_{2} \mathrm{O}$}

${ }^{15} \mathrm{O}-\mathrm{H}_{2} \mathrm{O}\left({ }^{15} \mathrm{O}\right.$ half-life $\left.=122 \mathrm{~s}\right)$ is used as a diffusible tracer to quantify regional myocardial perfusion by PET with multiple intravenous injections. Both the RIDIC group and the ICRP used a flow-based model of radiopharmaceutical distribution with data from the study of Herscovich et al. (19) and other sources (Table 9). The doses were very similar, and the effective doses differed by less than $10 \%$.

TABLE 4

Radiation Dosimetry for ${ }^{99 \mathrm{mTc}} \mathrm{Tc}$ Tetrofosmin in Adults, According to ICRP Task Group (6)

\begin{tabular}{llc}
\hline & \multicolumn{2}{c}{$\begin{array}{c}\text { Estimated dose } \\
\text { (mSv/MBq) }\end{array}$} \\
\cline { 2 - 3 } Organ & Resting & Exercise \\
\hline Adrenal glands & $3.4 \mathrm{E}-03$ & $3.3 \mathrm{E}-03$ \\
Brain & $3.9 \mathrm{E}-04$ & $4.6 \mathrm{E}-04$ \\
Breasts & $9.0 \mathrm{E}-04$ & $1.0 \mathrm{E}-03$ \\
\hline Gallbladder wall & $3.6 \mathrm{E}-02$ & $2.7 \mathrm{E}-02$ \\
Lower large intestine wall & $2.0 \mathrm{E}-02$ & $1.5 \mathrm{E}-02$ \\
\hline Small intestine & $1.5 \mathrm{E}-02$ & $1.1 \mathrm{E}-02$ \\
Stomach wall & $3.7 \mathrm{E}-03$ & $3.5 \mathrm{E}-03$ \\
Upper large intestine wall & $2.7 \mathrm{E}-02$ & $2.0 \mathrm{E}-02$ \\
\hline Heart wall & $4.4 \mathrm{E}-03$ & $4.8 \mathrm{E}-03$ \\
\hline Kidneys & $1.4 \mathrm{E}-02$ & $1.1 \mathrm{E}-02$ \\
Liver & $4.0 \mathrm{E}-03$ & $3.3 \mathrm{E}-03$ \\
\hline Lungs & $2.0 \mathrm{E}-03$ & $2.2 \mathrm{E}-03$ \\
Muscle & $3.7 \mathrm{E}-03$ & $4.1 \mathrm{E}-03$ \\
Ovaries & $8.4 \mathrm{E}-03$ & $7.6 \mathrm{E}-03$ \\
Pancreas & $4.1 \mathrm{E}-03$ & $3.9 \mathrm{E}-03$ \\
\hline Red marrow & $2.9 \mathrm{E}-03$ & $2.9 \mathrm{E}-03$ \\
Bone surfaces & $4.5 \mathrm{E}-03$ & $4.8 \mathrm{E}-03$ \\
\hline Skin & $1.3 \mathrm{E}-03$ & $1.4 \mathrm{E}-03$ \\
\hline Spleen & $3.0 \mathrm{E}-03$ & $3.0 \mathrm{E}-03$ \\
\hline Testes & $2.4 \mathrm{E}-03$ & $2.9 \mathrm{E}-03$ \\
\hline Thymus & $2.1 \mathrm{E}-03$ & $2.4 \mathrm{E}-03$ \\
\hline Thyroid & $5.7 \mathrm{E}-03$ & $4.8 \mathrm{E}-03$ \\
\hline Urinary bladder wall & $1.7 \mathrm{E}-02$ & $2.6 \mathrm{E}-02$ \\
\hline Uterus & $7.2 \mathrm{E}-03$ & $7.6 \mathrm{E}-03$ \\
\hline Effective dose & $7.6 \mathrm{E}-03$ & $7.0 \mathrm{E}-03$ \\
\hline & & \\
\hline & & \\
\hline
\end{tabular}


TABLE 5

Radiation Dosimetry for ${ }^{18} \mathrm{~F}-\mathrm{FDG}$

\begin{tabular}{|llll}
\hline & \multicolumn{3}{c}{ Dose (mSv/MBq) estimated by: } \\
\cline { 2 - 4 } Organ & RIDIC (8) & MIRD (15) & ICRP $(6)$ \\
\hline Adrenal glands & $1.3 \mathrm{E}-02$ & & $1.2 \mathrm{E}-02$ \\
\hline Brain & $1.9 \mathrm{E}-02$ & $4.6 \mathrm{E}-02$ & $2.8 \mathrm{E}-02$ \\
\hline Breasts & $9.2 \mathrm{E}-03$ & & $8.6 \mathrm{E}-03$ \\
\hline Gallbladder wall & $1.4 \mathrm{E}-02$ & & $1.2 \mathrm{E}-02$ \\
\hline Lower large intestine wall & $1.7 \mathrm{E}-02$ & & $1.5 \mathrm{E}-02$ \\
\hline Small intestine & $1.4 \mathrm{E}-02$ & & $1.3 \mathrm{E}-02$ \\
\hline Stomach wall & $1.3 \mathrm{E}-02$ & & $1.1 \mathrm{E}-02$ \\
\hline Upper large intestine wall & $1.3 \mathrm{E}-02$ & & $1.2 \mathrm{E}-02$ \\
\hline Heart wall & $6.0 \mathrm{E}-02$ & $6.8 \mathrm{E}-02$ & $6.2 \mathrm{E}-02$ \\
\hline Kidneys & $2.0 \mathrm{E}-02$ & $2.1 \mathrm{E}-02$ & $2.1 \mathrm{E}-02$ \\
\hline Liver & $1.6 \mathrm{E}-02$ & $2.4 \mathrm{E}-02$ & $1.1 \mathrm{E}-02$ \\
\hline Lungs & $1.7 \mathrm{E}-02$ & $1.5 \mathrm{E}-02$ & $1.0 \mathrm{E}-02$ \\
\hline Muscle & $1.1 \mathrm{E}-02$ & & $1.1 \mathrm{E}-02$ \\
\hline Ovaries & $1.7 \mathrm{E}-02$ & $1.1 \mathrm{E}-02$ & $1.5 \mathrm{E}-02$ \\
\hline Pancreas & $2.6 \mathrm{E}-02$ & $1.4 \mathrm{E}-02$ & $1.2 \mathrm{E}-02$ \\
\hline Red marrow & $1.3 \mathrm{E}-02$ & $1.1 \mathrm{E}-02$ & $1.1 \mathrm{E}-02$ \\
\hline Bone surfaces & $1.2 \mathrm{E}-02$ & & $1.1 \mathrm{E}-02$ \\
\hline Skin & $8.4 \mathrm{E}-03$ & & $8.0 \mathrm{E}-03$ \\
\hline Spleen & $3.7 \mathrm{E}-02$ & $1.5 \mathrm{E}-02$ & $1.1 \mathrm{E}-02$ \\
\hline Testes & $1.3 \mathrm{E}-02$ & $1.1 \mathrm{E}-02$ & $1.2 \mathrm{E}-02$ \\
\hline Thymus & $1.2 \mathrm{E}-02$ & & $1.1 \mathrm{E}-02$ \\
\hline Thyroid & $1.0 \mathrm{E}-02$ & & $1.0 \mathrm{E}-02$ \\
\hline Urinary bladder wall & $1.9 \mathrm{E}-01$ & $7.3 \mathrm{E}-022^{*}$ & $1.6 \mathrm{E}-01$ \\
\hline Uterus & $2.3 \mathrm{E}-02$ & & $2.1 \mathrm{E}-02$ \\
\hline Effective dose & $3.0 \mathrm{E}-02$ & $1.6 \mathrm{E}-02$ & $1.9 \mathrm{E}-02$ \\
\hline & & & \\
\hline
\end{tabular}

*Dose to urinary bladder wall is based on 120-min void intervals, starting $120 \mathrm{~min}$ after administration.

${ }^{\dagger}$ Not provided by authors; estimated from input data.

Therefore, either set of dosimetry values may be used, but the ICRP values are nonetheless preferred because they are based on several data sources that drew conclusions similar to those of Herscovich et al.

\section{DISCUSSION}

The dose estimates noted here for several agents vary notably among publications by different groups, a fact that can be confusing for the practicing physician or researcher. Which model is better? Are the observed differences between 2 dose estimates significant, or are they within the uncertainties of the data? Table 10 shows a summary of the radiation doses discussed here, along with the typical administered activities for the respective procedures, so that the actual total doses estimated to be received by subjects can be compared. The effective doses for all agents are about 2-15 mSv per study, with the lowest values being noted for ${ }^{13} \mathrm{~N}_{-} \mathrm{NH}_{3}$ and ${ }^{15} \mathrm{O}-\mathrm{H}_{2} \mathrm{O}$ studies. The doses per study for ${ }^{99 \mathrm{~m}} \mathrm{Tc}-$ and ${ }^{201} \mathrm{Tl}$-labeled agents differed by about a factor of 2; this difference must be assessed in the context of the numeric uncertainty in individual values.

\section{Uncertainties in Internal Dose Calculations}

For evaluation of the overall uncertainty in a radiation dose estimate, the uncertainty in each of the contributing terms must be considered, as described in a separate recent study (20). The conclusions of the analysis are that internal dose estimates for diagnostic agents are model based, not based on measurements for individual subjects, and carry significant inherent uncertainties. The largest contributions to uncertainty are related to the following factors:

- With regard to the phantom-related parameters $\phi$ (absorbed fraction of energy) and $\mathrm{m}$ (target organ mass), the $\phi$ values themselves have relatively low uncertainties. However, their application to a population of individuals with variations from the median represented in the model introduces significant uncertainties, of at least tens of percentage points.

- The biokinetic parameters inherent in the calculation of the number of disintegrations occurring in source regions, namely, fractional uptake and effective halftime in organs and the body, vary substantially among individuals. Variability of a factor of 2 or more is a reasonable assumption for the kinetics of any given radiopharmaceutical. If data are extrapolated from animal data, then dose estimates will tend to underestimate human dose estimates, and the $90 \%$ confidence interval for human organ cumulated activities

TABLE 6

Radiation Dosimetry for ${ }^{82} \mathrm{Rb}$-Chloride in Adults

\begin{tabular}{llc}
\hline & \multicolumn{2}{c}{$\begin{array}{c}\text { Dose }(\mathrm{mSv} / \mathrm{MBq}) \\
\text { estimated by: }\end{array}$} \\
\cline { 2 - 3 } Organ & $\mathrm{RIDIC}(8)$ & $\mathrm{ICRP}(6)$ \\
\hline Adrenal glands & $4.4 \mathrm{E}-04$ & $2.0 \mathrm{E}-02$ \\
\hline Brain & $3.2 \mathrm{E}-04$ & \\
Breasts & $3.3 \mathrm{E}-04$ & $1.9 \mathrm{E}-04$ \\
\hline Gallbladder wall & $4.2 \mathrm{E}-04$ & \\
\hline Lower large intestine wall & $3.6 \mathrm{E}-04$ & $3.9 \mathrm{E}-03$ \\
\hline Small intestine & $3.8 \mathrm{E}-04$ & $3.9 \mathrm{E}-03$ \\
\hline Stomach wall & $3.8 \mathrm{E}-04$ & $3.8 \mathrm{E}-03$ \\
\hline Upper large intestine wall & $3.8 \mathrm{E}-04$ & $3.9 \mathrm{E}-03$ \\
\hline Heart wall & $1.8 \mathrm{E}-03$ & $3.3 \mathrm{E}-03$ \\
\hline Kidneys & $9.0 \mathrm{E}-03$ & $1.8 \mathrm{E}-02$ \\
\hline Liver & $8.3 \mathrm{E}-04$ & $9.7 \mathrm{E}-04$ \\
\hline Lungs & $1.7 \mathrm{E}-03$ & $2.4 \mathrm{E}-03$ \\
\hline Muscle & $3.5 \mathrm{E}-04$ & \\
\hline Ovaries & $3.7 \mathrm{E}-04$ & $2.4 \mathrm{E}-04$ \\
\hline Pancreas & $4.2 \mathrm{E}-04$ & $4.5 \mathrm{E}-03$ \\
\hline Red marrow & $4.5 \mathrm{E}-04$ & $9.9 \mathrm{E}-04$ \\
\hline Bone surfaces & $3.3 \mathrm{E}-04$ & $6.7 \mathrm{E}-04$ \\
\hline Skin & $3.2 \mathrm{E}-04$ & \\
\hline Spleen & $4.1 \mathrm{E}-04$ & $5.0 \mathrm{E}-03$ \\
\hline Testes & $2.6 \mathrm{E}-04$ & $1.3 \mathrm{E}-04$ \\
\hline Thymus & $3.7 \mathrm{E}-04$ & \\
\hline Thyroid & $3.4 \mathrm{E}-04$ & $3.8 \mathrm{E}-02$ \\
\hline Urinary bladder wall & $3.6 \mathrm{E}-04$ & $1.7 \mathrm{E}-04$ \\
\hline Uterus & $3.7 \mathrm{E}-04$ & $2.1 \mathrm{E}-04$ \\
\hline Effective dose & $7.9 \mathrm{E}-04$ & $3.4 \mathrm{E}-03$ \\
\hline & & \\
\hline & & \\
\hline
\end{tabular}


TABLE 7

Radiation Dosimetry for ${ }^{13} \mathrm{~N}-\mathrm{NH}_{3}$ in Adults

\begin{tabular}{|c|c|c|}
\hline \multirow[b]{2}{*}{ Organ } & \multicolumn{2}{|c|}{$\begin{array}{c}\text { Dose (mSv/MBq) } \\
\text { estimated by: }\end{array}$} \\
\hline & ICRP (6) & RIDIC (8) \\
\hline Adrenal glands & $2.3 E-03$ & 1.7E-03 \\
\hline Brain & $4.2 \mathrm{E}-03$ & $4.7 \mathrm{E}-03$ \\
\hline Breasts & $1.8 \mathrm{E}-03$ & $1.3 \mathrm{E}-03$ \\
\hline Gallbladder wall & & $1.9 \mathrm{E}-03$ \\
\hline Lower large intestine wall & $1.9 \mathrm{E}-03$ & $1.7 \mathrm{E}-03$ \\
\hline Small intestine & $1.8 \mathrm{E}-03$ & $1.7 \mathrm{E}-03$ \\
\hline Stomach wall & $1.7 \mathrm{E}-03$ & $1.6 \mathrm{E}-03$ \\
\hline Upper large intestine wall & $1.8 \mathrm{E}-03$ & $1.7 \mathrm{E}-03$ \\
\hline Heart wall & $2.1 \mathrm{E}-03$ & $1.6 \mathrm{E}-03$ \\
\hline Kidneys & $4.6 \mathrm{E}-03$ & $1.6 \mathrm{E}-03$ \\
\hline Liver & $4.0 E-03$ & $3.8 \mathrm{E}-03$ \\
\hline Lungs & $2.5 E-03$ & $1.5 \mathrm{E}-03$ \\
\hline Muscle & & $1.4 \mathrm{E}-03$ \\
\hline Ovaries & $1.7 \mathrm{E}-03$ & $1.7 \mathrm{E}-03$ \\
\hline Pancreas & $1.9 \mathrm{E}-03$ & $1.7 \mathrm{E}-03$ \\
\hline Red marrow & $1.7 \mathrm{E}-03$ & $1.8 \mathrm{E}-03$ \\
\hline Bone surfaces & $1.6 \mathrm{E}-03$ & $1.5 \mathrm{E}-03$ \\
\hline Skin & & $1.2 \mathrm{E}-03$ \\
\hline Spleen & $2.5 E-03$ & $1.5 \mathrm{E}-03$ \\
\hline Testes & $1.8 E-03$ & $1.4 \mathrm{E}-03$ \\
\hline Thymus & & $1.5 \mathrm{E}-03$ \\
\hline Thyroid & $1.7 \mathrm{E}-03$ & $1.5 \mathrm{E}-03$ \\
\hline Urinary bladder wall & $8.1 \mathrm{E}-03$ & $6.9 \mathrm{E}-03$ \\
\hline Uterus & $1.9 \mathrm{E}-03$ & $1.8 \mathrm{E}-03$ \\
\hline Effective dose & $2.0 E-03$ & $2.0 E-03$ \\
\hline
\end{tabular}

probably will be an order of magnitude around the corresponding animal cumulated activities.

- Changes in tissue weighting factors over time introduce additional differences in reported effective doses of up to $20 \%-40 \%$. This uncertainty may not be expected. Table 11 shows the differences in effective dose estimates obtained with 3 sets of ICRP weighting factors published at different times (21-23). A similar analysis was provided by Einstein et al. (24); except for the 1979 ICRP values, good agreement with the values shown in Table 11 was obtained. The central result is the same-that reported effective doses vary by some tens of percentage points, depending on which set of tissue weighting factors is applied to a given set of organ absorbed doses. Einstein et al. also correctly pointed out that substantial differences often occur between published sets of dose estimates from groups such as the ICRP and dose estimates appearing in manufacturer package inserts, in which dosimetry data often are not up to date.

The combined uncertainty in applying any given radiopharmaceutical dose estimate for a median individual with a set of biokinetic data to any individual nuclear medicine patient is therefore, at a minimum, a factor of 2 and is perhaps considerably greater. In therapy applications, with accurate image-based quantification of organ activities and measurement of patient-specific biokinetic parameters and organ volumes, many of the model-based uncertainties can be removed, and the total uncertainty can be reduced to a value of perhaps $\pm 10 \%-20 \%$ (25). For diagnostic studies, reliance on standardized models for biokinetics and for body geometry will probably continue to be the normal practice, and uncertainties of factors of 2 or more in any given value are reasonable to assume. Two other authors who have addressed this issue have concluded that internal dose estimates may vary by up to a factor of $3(26,27)$. In theory, uncertainties in dose estimates can be propagated by using what is known about population variability in body size, but knowledge of variability in biokinetic parameters is often more limited. This does not mean that radiation dose estimates should be treated as meaningless guesses, because they result from the careful application of the best available data and models and provide reasonable average values for planning purposes. Differences in dose estimates between any 2 radiopharmaceuticals should be appreciated and considered in overall planning for the use of various diagnostic techniques, but small differences in dose estimates between radiopharmaceuticals should not be considered decisive in choosing radiopharmaceuticals for broad

TABLE 8

Radiation Dosimetry for ${ }^{99 m}$ Tc-Labeled RBCs

\begin{tabular}{|c|c|c|c|}
\hline \multirow[b]{2}{*}{ Organ } & \multicolumn{3}{|c|}{ Dose (mSv/MBq) estimated by: } \\
\hline & $\begin{array}{l}\text { RIDIC (8), in } \\
\text { vitro labeling }\end{array}$ & $\begin{array}{l}\text { RIDIC (8), in } \\
\text { vivo labeling }\end{array}$ & ICRP (6) \\
\hline Adrenal glands & $5.0 \mathrm{E}-03$ & $5.4 \mathrm{E}-03$ & $9.9 \mathrm{E}-03$ \\
\hline Brain & $2.6 \mathrm{E}-03$ & $2.8 \mathrm{E}-03$ & $3.6 \mathrm{E}-03$ \\
\hline Breasts & $3.0 \mathrm{E}-03$ & $3.3 E-03$ & $3.5 E-03$ \\
\hline Gallbladder wall & $4.7 \mathrm{E}-03$ & $5.1 \mathrm{E}-03$ & $6.5 \mathrm{E}-03$ \\
\hline $\begin{array}{l}\text { Lower large } \\
\text { intestine wall }\end{array}$ & $4.5 \mathrm{E}-03$ & $4.6 \mathrm{E}-03$ & $3.4 \mathrm{E}-03$ \\
\hline Small intestine & $4.2 \mathrm{E}-03$ & $4.5 \mathrm{E}-03$ & $3.9 \mathrm{E}-03$ \\
\hline Stomach wall & $4.2 E-03$ & $4.6 \mathrm{E}-03$ & $4.6 \mathrm{E}-03$ \\
\hline $\begin{array}{l}\text { Upper large } \\
\text { intestine wall }\end{array}$ & $4.1 \mathrm{E}-03$ & $4.4 \mathrm{E}-03$ & $4.0 \mathrm{E}-03$ \\
\hline Heart & $1.5 \mathrm{E}-02$ & $1.6 \mathrm{E}-02$ & $2.3 \mathrm{E}-02$ \\
\hline Kidneys & $6.6 \mathrm{E}-03$ & $6.9 \mathrm{E}-03$ & $1.8 \mathrm{E}-02$ \\
\hline Liver & $6.1 E-03$ & $6.5 E-03$ & $1.3 E-02$ \\
\hline Lungs & $1.1 \mathrm{E}-02$ & $1.2 \mathrm{E}-02$ & $1.8 \mathrm{E}-02$ \\
\hline Muscle & $3.4 \mathrm{E}-03$ & $3.6 \mathrm{E}-03$ & $3.3 \mathrm{E}-03$ \\
\hline Ovaries & $4.7 E-03$ & $4.7 \mathrm{E}-03$ & $3.7 \mathrm{E}-03$ \\
\hline Pancreas & $5.3 E-03$ & $5.7 \mathrm{E}-03$ & $6.6 \mathrm{E}-03$ \\
\hline Red marrow & $3.8 E-03$ & $4.1 \mathrm{E}-03$ & $6.1 E-03$ \\
\hline Bone surfaces & $6.1 \mathrm{E}-03$ & $6.6 \mathrm{E}-03$ & $7.4 \mathrm{E}-03$ \\
\hline Skin & $2.2 \mathrm{E}-03$ & $2.3 E-03$ & $2.0 E-03$ \\
\hline Spleen & $1.1 \mathrm{E}-02$ & $1.2 \mathrm{E}-02$ & $1.4 \mathrm{E}-02$ \\
\hline Testes & $3.3 \mathrm{E}-03$ & $3.3 \mathrm{E}-03$ & $2.3 \mathrm{E}-03$ \\
\hline Thymus & $5.3 E-03$ & $5.7 \mathrm{E}-03$ & $6.1 \mathrm{E}-03$ \\
\hline Thyroid & $3.3 E-03$ & $3.6 \mathrm{E}-03$ & $5.7 \mathrm{E}-03$ \\
\hline Urinary bladder wall & $2.1 E-02$ & $1.5 E-02$ & $8.5 E-03$ \\
\hline Uterus & $5.8 \mathrm{E}-03$ & $5.4 \mathrm{E}-03$ & $3.9 \mathrm{E}-03$ \\
\hline Effective dose & $6.1 E-03$ & $6.1 E-03$ & $7.0 \mathrm{E}-03$ \\
\hline
\end{tabular}


TABLE 9

Radiation Dosimetry for ${ }^{15} \mathrm{O}-\mathrm{H}_{2} \mathrm{O}$

\begin{tabular}{lll}
\hline & \multicolumn{2}{c}{$\begin{array}{c}\text { Dose (mSv/MBq) } \\
\text { estimated by: }\end{array}$} \\
\cline { 2 - 3 } Organ & RIDIC $(8)$ & ICRP $(6)$ \\
\hline Adrenal glands & $1.3 \mathrm{E}-03$ & $1.4 \mathrm{E}-03$ \\
\hline Brain & $1.3 \mathrm{E}-03$ & $1.3 \mathrm{E}-03$ \\
\hline Breasts & $3.0 \mathrm{E}-04$ & $2.8 \mathrm{E}-04$ \\
\hline Gallbladder wall & $4.5 \mathrm{E}-04$ & $4.5 \mathrm{E}-04$ \\
\hline Lower large intestine wall & $7.4 \mathrm{E}-04$ & $1.1 \mathrm{E}-03$ \\
\hline Small intestine & $9.3 \mathrm{E}-04$ & $1.3 \mathrm{E}-03$ \\
\hline Stomach wall & $5.3 \mathrm{E}-04$ & $7.8 \mathrm{E}-04$ \\
\hline Upper large intestine wall & $7.0 \mathrm{E}-04$ & $1.0 \mathrm{E}-03$ \\
\hline Heart wall & $2.2 \mathrm{E}-03$ & $1.9 \mathrm{E}-03$ \\
\hline Kidneys & $1.9 \mathrm{E}-03$ & $1.7 \mathrm{E}-03$ \\
\hline Liver & $1.5 \mathrm{E}-03$ & $1.6 \mathrm{E}-03$ \\
\hline Lungs & $1.9 \mathrm{E}-03$ & $1.6 \mathrm{E}-03$ \\
\hline Muscle & $2.7 \mathrm{E}-04$ & $2.9 \mathrm{E}-04$ \\
\hline Ovaries & $3.6 \mathrm{E}-04$ & $8.5 \mathrm{E}-04$ \\
\hline Pancreas & $1.6 \mathrm{E}-03$ & $1.4 \mathrm{E}-03$ \\
\hline Red marrow & $9.0 \mathrm{E}-04$ & $8.5 \mathrm{E}-04$ \\
\hline Bone surfaces & $5.2 \mathrm{E}-04$ & $6.2 \mathrm{E}-04$ \\
\hline Skin & $2.6 \mathrm{E}-04$ & $2.5 \mathrm{E}-04$ \\
\hline Spleen & $1.6 \mathrm{E}-03$ & $1.6 \mathrm{E}-03$ \\
\hline Testes & $6.7 \mathrm{E}-04$ & $7.4 \mathrm{E}-04$ \\
\hline Thymus & $3.6 \mathrm{E}-04$ & $3.3 \mathrm{E}-04$ \\
\hline Thyroid & $1.7 \mathrm{E}-03$ & $1.5 \mathrm{E}-03$ \\
\hline Urinary bladder wall & $2.2 \mathrm{E}-04$ & $2.6 \mathrm{E}-04$ \\
\hline Uterus & $3.4 \mathrm{E}-04$ & $3.5 \mathrm{E}-04$ \\
\hline Effective dose & $1.1 \mathrm{E}-03$ & $9.3 \mathrm{E}-04$ \\
\hline & & \\
\hline & & \\
\hline
\end{tabular}

uses in nuclear medicine patients. Considerations such as diagnostic power, ease of use, image quality, patient comfort, and other, similar factors should generally dictate the choice of a radiopharmaceutical, with radiation dose being only a secondary or tertiary consideration.

Similar uncertainties encountered in the use of other modalities with ionizing radiation in cardiology examinations should be considered as well. Dose estimates for these studies (e.g., CT and fluoroscopy) are often based on the use of the same anthropomorphic models as those discussed earlier. Practices vary substantially between diagnostic centers as well. For example, in the Nationwide Evaluation of X-ray Trends (NEXT) 2000 Survey of CT conducted by the Conference of Radiation Control Program Directors, Inc. (28), effective dose levels (mean \pm 1 SD) were reported to be $1.2 \pm 0.7 \mathrm{mSv}$ for head studies and $13.7 \pm$ $7.1 \mathrm{mSv}$ for abdominal studies. The variability was attributed to differences in the radiation outputs of different scanners for the same model under the same conditions of operation and the imprecision of probe or phantom positioning, which might cause variations in scattered-radiation contributions to measured values. Therefore, effective doses in abdominal studies vary over a range similar to that discussed earlier.

One of the motivations for this work was to answer reasonable questions from nuclear cardiologists about whether a particular radiopharmaceutical is preferable over

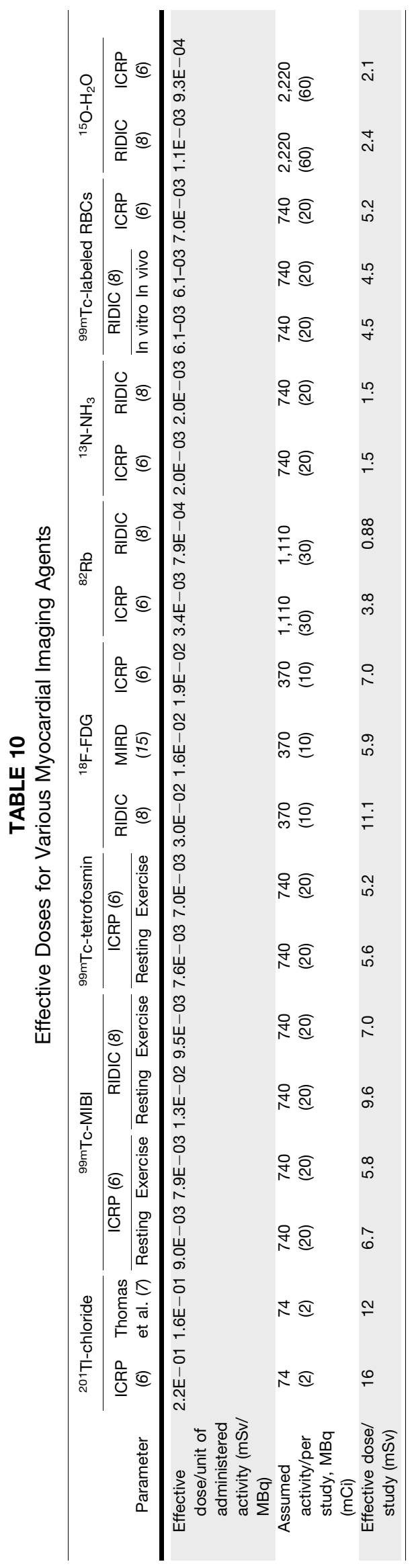

Dosimetry in Nuclear CARdiology • Stabin 
TABLE 11

Doses of Various Myocardial Imaging Agents Estimated from ICRP Tissue Weighting Factors and Administered Activity Values from Table 10

\begin{tabular}{|c|c|c|c|}
\hline \multirow[b]{2}{*}{ Agent } & \multicolumn{3}{|c|}{$\begin{array}{l}\text { Dose (mSv) estimated } \\
\quad \text { from ICRP tissue } \\
\text { weighting factors from: }\end{array}$} \\
\hline & 1979 & 1991 & 2007 \\
\hline${ }^{201} \mathrm{Tl}$-chloride & 12.7 & 10.4 & 10.0 \\
\hline 99mTc-MIBI resting & $8.2^{*}$ & 6.5 & 6.4 \\
\hline 99mTc-MIBI exercise & $7.8^{*}$ & 5.7 & 5.6 \\
\hline 99mTc-tetrofosmin resting & $7.4^{*}$ & 5.4 & 5.0 \\
\hline 99mTc-tetrofosmin exercise & $6.6^{*}$ & 5.1 & 4.6 \\
\hline${ }^{82} \mathrm{Rb}$ & 5.3 & 4.2 & 4.2 \\
\hline${ }^{13} \mathrm{~N}-\mathrm{NH}_{3}$ & 2.0 & 1.7 & 1.6 \\
\hline${ }^{18} \mathrm{~F}-\mathrm{FDG}$ & 9.2 & 7.4 & 6.9 \\
\hline${ }^{15} \mathrm{O}-\mathrm{H}_{2} \mathrm{O}$ & $2.1^{*}$ & 2.2 & 2.1 \\
\hline
\end{tabular}

${ }^{\star}$ Not reported by ICRP; estimated from ICRP biokinetic data.

another on the basis of the relative risks of particular studies. The analysis described here has shown that differences in most of the radiation dose estimates for the various compounds are small compared with the absolute uncertainty in their values. The issue of risk at low doses (such as those associated with diagnostic procedures) is generally addressed with the linear, no-threshold (LNT) doseresponse model. Some advocate the use of this model to predict population or individual numeric estimates of risk; others believe that it should not be used in this way. The LNT model is exactly that, a model. The available data that show quantitative relationships between excess risk of cancer induction and exposure to radiation are reliable down to only $100 \mathrm{mGy}$ (10 rads), at the very lowest, and most data are useful only above $200-500 \mathrm{mGy}(20-50 \mathrm{rad})$. It has been assumed that the model may extend linearly down to lower doses solely for the purposes of setting policy, such as determining radiation dose limits for radiation workers and setting reasonable guidelines for exposure of the general public. It is not known for a fact that radiation at the low levels experienced in diagnostic medical examinations, even when several such examinations have occurred in a short time, causes any untoward effects at all. The data may be said to be "not inconsistent with" (29) a linear model with no threshold; therefore, it may be reasonable to use the model for the purposes stated earlier. However, the use of the LNT model with numeric estimates of doses to project population cancer deaths or, worse, cancer risk estimates for individual patients is a misuse of the model.

Mettler (30) and Brenner and Hall (31) pointed out that when patients receive repeated CT, PET/CT, or SPECT/CT studies over short periods of time, the cumulative doses received can approach the lowest dose levels at which some authors have claimed to show statistically significant increases in cancer risk in Japanese survivors of atomic bomb radiation (32). However, the numeric uncertainties in these risk estimates, as well as in the dose estimates against which they are extrapolated, are substantial (29), and there are several complicating factors in the interpretation of these results. These include the fact that the radiation doses were delivered at very high dose rates; the total doses included a significant neutron component; the subjects were exposed to fallout radiation, which resulted in internal doses, as well as to many other carcinogens; and other factors. Therefore, it remains an assumption that doses at the high end of the diagnostic range are carcinogenic. It remains prudent to limit the amount of radiation given in any particular study and to avoid unnecessary repeat studies; on the other hand, needed medical studies should never be avoided because of concerns over the very small and theoretic radiation risks involved, because the benefits of the study (i.e., the risks of not performing the study) always substantially outweigh these very low, theoretic risks (33).

\section{CONCLUSION}

Radiation dose estimates for radiopharmaceuticals used in nuclear cardiology may vary, depending on the source of data used in their generation. Uncertainties in applying dose estimates to individual subjects or populations are considerable because of the use of standardized biokinetic and anatomic models. Considerations such as diagnostic accuracy, ease of use, image quality, and patient comfort and convenience should generally dictate the choice of a radiopharmaceutical, with radiation dose being only a secondary or even a tertiary consideration. Counseling of nuclear medicine patients who may be concerned about exposure should include a reasonable estimate of the median dose for the type of examination and administered activity of the radiopharmaceutical; in addition, it should be explained that the theoretic risks of the procedure are orders of magnitude lower than the actual benefits of the examination.

\section{ACKNOWLEDGMENT}

This article was produced in consultation with the RAdiation Dose Assessment Resource (RADAR) Task Group of the Society of Nuclear Medicine.

\section{REFERENCES}

1. Atkins HL, Budinger TF, Lebowitz E, et al. Thallium-201 for medical use, part 3: human distribution and physical imaging properties. J Nucl Med. 1977;18: 133-140.

2. Krahwinkel W, Herzog H, Feinendegen LE. Pharmacokinetics of thallium-201 in normal individuals after routine myocardial scintigraphy. J Nucl Med. 1988;29: 1582-1586.

3. Castronovo FP Jr. ${ }^{201} \mathrm{Tl}$-labelled $\mathrm{TlCl}$ dosimetry revisited. Nucl Med Commun. 1993;14:104-107.

4. Gupta SM, Herrera N, Spencer RP, et al. Testicular-scrotal content of Tl-201 and Ga-67 after intravenous administration. Int J Nucl Med Biol. 1981;8:211-213.

5. Hosain P, Hosain F. Revision of gonadal radiation dose to man from thallium201. In: Proceedings of the Third International Radiopharmaceutical Dosimetry Symposium. Oak Ridge, TN: Oak Ridge Associated Universities; 1981:333-345. 
6. International Commission on Radiological Protection. Radiation Dose to Patients from Radiopharmaceuticals. New York, NY: Pergamon Press; 1988. ICRP Publication 53.

7. Thomas SR, Stabin MG, Castronovo FP. Radiation-absorbed dose from ${ }^{201} \mathrm{Tl}-$ thallous chloride. J Nucl Med. 2005;46:502-508.

8. Stabin MG, Stubbs JB, Toohey RE. Radiation Dose Estimates for Radiopharmaceuticals. Washington, DC: U.S. Nuclear Regulatory Commission, U.S. Department of Energy, U.S. Department of Health and Human Services; 1996. NUREG/CR-6345.

9. Wackers FJ, Berman DS, Maddahi J, et al. Technetium- $99 \mathrm{~m}$ hexakis 2-methoxyisobutyl isonitrile: human biodistribution, dosimetry, safety, and preliminary comparison to thallium-201 for myocardial perfusion imaging. J Nucl Med. 1989;30:301-311.

10. Leide S, Diemer H, Ahlgren L, et al. In vivo distribution and dosimetry of Tc-99m MIBI in man. In: Stelson A, Watson E, eds. Fifth International Radiopharmaceutical Dosimetry Symposium. Oak Ridge, TN: Oak Ridge Associated Universities; 1992:483-497. CONF-910529.

11. Smith T, Lahiri A, Gemmell HG, et al. Dosimetry of ${ }^{99 \mathrm{~m}} \mathrm{Tc}-\mathrm{P} 53$, a new myocardial perfusion imaging agent. In: Stelson A, Watson E, eds. Fifth International Radiopharmaceutical Dosimetry Symposium. Oak Ridge, TN: Oak Ridge Associated Universities; 1992:467-481. CONF-910529.

12. Higley B, Smith FW, Smith T, et al. Technetium-99m-1,2-bis[bis(2ethoxyethyl)phosphino]ethane: human biodistribution, dosimetry, and safety of a new myocardial perfusion imaging agent. J Nucl Med. 1993;34:30-38.

13. Gallagher BM, Ansari A, Atkins H, et al. ${ }^{18} \mathrm{~F}$-labeled 2-deoxy-2-fluoro-D-glucose as a radiopharmaceutical for measuring regional myocardial glucose metabolism in vivo: tissue distribution and imaging studies in animals. J Nucl Med. 1977; 18:990-996.

14. Jones SC, Alavi A, Christman D, Montanez I, Wolf AP, Reivich M. The radiation dosimetry of 2-[F-18]fluoro-2-deoxy-D-glucose in man. J Nucl Med. 1982;23: 613-617.

15. Hays MT, Watson EE, Thomas SR, Stabin M. Radiation absorbed dose estimates from ${ }^{18}$ F-FDG. MIRD Pamphlet No. 19. J Nucl Med. 2002;43:210-214.

16. Ryan JW, Harper PV, Stark VS, Peterson EL, Lathrop KA. Radiation absorbed dose estimate for rubidium-82 determined from in-vivo measurements in human subjects. In: Fourth International Radiopharmaceutical Dosimetry Symposium. Oak Ridge, TN: Oak Ridge Associated Universities. 1985:346-358.

17. Lockwood AH, McDonald JM, Reiman RE, et al. The dynamics of ammonia metabolism in man: effects of liver disease and hyperammonemia. J Clin Invest. 1979;63:449-460.

18. Atkins HL, Thomas SR, Buddemeyer U, Chervu LR. Radiation absorbed dose from technetium-99m-labeled red blood cells. MIRD Pamphlet No. 14. J Nucl Med. 1990;31:378-380.
19. Herscovich P, Carson RE, Stabin M, et al. A new kinetic model approach to estimate the radiation dosimetry of flow-based radiotracers [abstract]. $\mathrm{J} \mathrm{Nucl}$ Med. 1993;34(suppl):155P.

20. Stabin MG. Uncertainties in internal dose calculations for radiopharmaceuticals. J Nucl Med. 2008;49:853-860.

21. International Commission on Radiological Protection. Limits for Intakes of Radionuclides by Workers. ICRP Publication 30. New York, NY: Pergamon Press; 1979.

22. International Commission on Radiological Protection. 1990 Recommendations of the International Commission on Radiological Protection. ICRP Publication 60. New York, NY: Pergamon Press; 1991.

23. International Commission on Radiological Protection. The 2007 Recommendations of the International Commission on Radiological Protection. ICRP Publication 103. Philadelphia, PA: Elsevier Health; 2007.

24. Einstein AJ, Moser KW, Thompson RC, Cerqueira MD, Henzlova MJ. Radiation dose to patients from cardiac diagnostic imaging. Circulation. 2007;116:12901305 .

25. Siegel JA, Thomas SR, Stubbs JB, et al. Techniques for quantitative radiopharmaceutical biodistribution data acquisition and analysis for use in human radiation dose estimates. MIRD Pamphlet No. 16. J Nucl Med. 1999;40(suppl): $37 \mathrm{~S}-61 \mathrm{~S}$.

26. Roedler HD. Accuracy of internal dose calculations with special consideration of radiopharmaceutical biokinetics. In: Third International Radiopharmaceutical Dosimetry Symposium. Rockville, MD: Department of Health and Human Welfare, Bureau of Radiological Health; 1981. HHS Publication (FDA 818166).

27. Zanzonico B. Internal radionuclide radiation dosimetry: a review of basic concepts and recent developments. J Nucl Med. 2000;41:297-308.

28. Stern SH. Nationwide Evaluation of X-ray Trends (NEXT) 2000 Survey of CT. Frankfort, KY: Conference of Radiation Control Program Directors, Inc.; 2007. CRCPD Publication E-07-2.

29. National Research Council of The National Academies. Health Risks from Exposure to Low Levels of Ionizing Radiation, Beir VII, Phase 2. Washington, DC: The National Academies Press; 2006.

30. Mettler FA. G. William Morgan Lecture: Growth of Radiation Uses in Medicine. Oakland, CA: Health Physics Society; 2008.

31. Brenner DJ, Hall EJ. Computed tomography: an increasing source of radiation exposure. N Engl J Med. 2007;357:2277-2284.

32. Pierce DA, Preston DL. Radiation-related cancer risks at low doses among atomic bomb survivors. Radiat Res. 2000;154:178-186.

33. Zanzonico P. Risk-benefit analysis: looking at both sides of the coin. Presented at: Annual Meeting of the American Society of Nuclear Cardiology; September 7, 2007; San Diego, CA. 